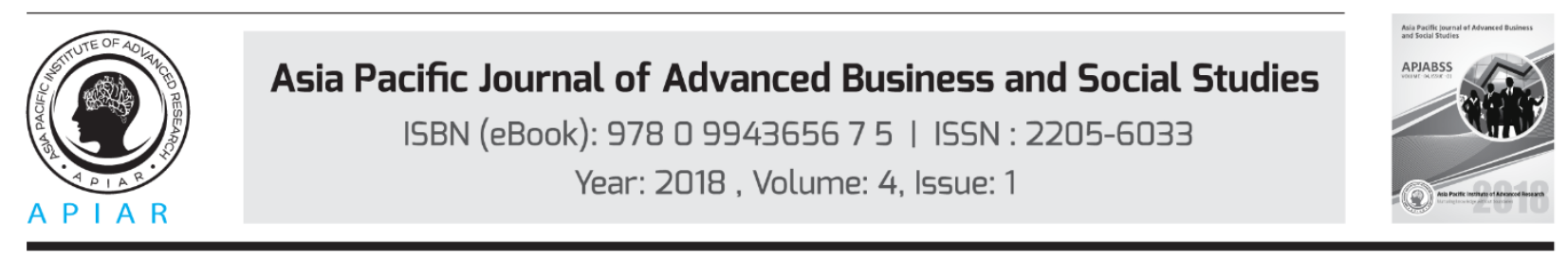

\title{
RESPONSIBILITY OR ATONEMENT? AN ANALYSIS OF CHINA'S CORPORATE PHILANTHROPY AND CORPORATE PERFORMANCE IN DIFFERENT INDUSTRIES
}

\author{
Wei Liu \\ The University of Sydney, Sydney, Australia \\ Email:wliu3540@uni.sydney.edu.au
}

\begin{abstract}
Corporate philanthropy has become one important strategy for firms to achieve social responsibility and is expected to affect corporate performance in a positive way. This study examines the philanthropic choice, the relationship between corporate philanthropy and corporate performance, and further investigates the moderating effect of political connection in different industries. Using a sample of China's listed firms, second data on financial data and hand-collected data on corporate philanthropy, the results show that past poor performance is a likelihood to make philanthropic choice, corporate philanthropy is positively associated with corporate performance, and the positive relationship is stronger in the industry with high-level political environment.
\end{abstract}

Keywords: Corporate Philanthropy, Corporate, Philanthropic Choice, Corporate Social Responsibility.

\section{Introduction}

Philanthropy is an important part of corporate social responsibility and also the obligation of corporations as "social citizens" (Patten 2008). With the intensification of global business competition, corporations integrate philanthropy into the overall strategic plans by considering resources and cost to achieve a win-win situation in economic and social benefits. Previous studies on the impact of corporate philanthropy on corporate performance are equivocal. Some scholars point out that the impact is positive because corporations can achieve benefits such as advertising effectiveness, building reputation, attracting resources from a good philanthropy strategy (File and Prince 1998, Porter and Kramer 2002). Some scholars argue that corporate philanthropy can cause pressure of cash flow and occupancy of effective resource (Aupperle, Carroll and Hatfield 1985; Windsor 2001). Though the academic debate on corporate philanthropy and corporate performance is inconclusive, it is determined that an exterior environment can affect corporate philanthropy and its impact on performance (Wang and Qian, 2011). Simultaneously, an interesting and meaningful topic in the research of the relationship between corporate philanthropy and corporate performance is the motivation of corporate philanthropic behavior. Compared to altruism, It is more likely to be recognized that corporate philanthropy acts as a business strategy in order to deal with external threats or improve the competitive environment (Campbell, Gulas and Gruca 1999; Porter and Kramer 2002; Sanchez 2000). 
Society in China has been deeply influenced by Confucianism and China's corporate strategic decisions are influenced by this unique exterior environment. Meanwhile, as Chinese traditional culture was shocked by Western modern culture for 19 centuries, the concept of China's philanthropy has gradually changed and was finally formed in recent years (Wang, Dou and Jia 2016). Serious natural disasters that occurred in China, such as SARS disease in 2003, or Wenchuan earthquake in 2008 forced corporations to exercise social responsibility by philanthropy and this improved corporation's understanding of philanthropic strategy and people's concern for corporate philanthropy. Previous studies focused on the relationship between corporate philanthropy and corporate performance and there is a research gap within China's exterior environment. So, this study aims to determine the motivation of corporate philanthropic behavior and identify the moderating effect of the exterior environment by comparing political environment in different industries based on the analysis of the relationship between corporate philanthropy and corporate performance.

This report contributes to the study on the relationship between corporate philanthropy and corporate performance in the following ways. First, the significant relationship between corporate philanthropy and corporate performance is validated in China's exterior environment. Based on the study of political system and cultural differences (Wang and Qian 2011, Wang, Choi and $\mathrm{Li}$ 2008), the empirical evidence can be provided to show that industry plays an important role in moderating the relationship. Second, this report contributes to the development of philanthropic theories. Previous literature mainly used Corporate Social Responsibility (CSR) as theoretical paths to study the motivations of corporate strategic philanthropy (Frooman, 1997; Porter and Kramer 2002; Wang and Coffey 1992). Resource Dependent Perspective (RDP) is used in this report as the theoretical path of moderating effect to explain the different corporate performance in different industries. Meanwhile, the theoretical analysis based on the combination of CSR and RDP is provided as a method to analyze corporate philanthropy decision making to maximize corporate performance under complex exterior environment. Third, the motivation of corporate philanthropic choice can be determined based on performance feedback. Existing research has not clearly explained the reasons that corporate decision-makers choose corporate philanthropy as a strategy. This study measured corporate past performance and established a relationship between past performance and philanthropic choice.

The following analysis is organized in several parts. The next section analyzes the relationship between corporate philanthropy and corporate performance from the theoretical level through literature review, then proposes the hypotheses of the study. Next, the empirical method that contains different variables with data source and the equation is provided. The results will be interpreted and discussed afterwards and limitations and conclusion are carried out in the last section.

\section{Literature Review and Hypotheses}

\section{Corporate Philanthropy in China}

There have been different opinions on study of motivations for corporate philanthropy. Campbell, Moore and Metzger, (2002) summed up four motivational perspectives: strategic motivations, altruistic motivations, political motivations and managerial utility motivations. Strategic motivational perspective was added by competitive advantage theory to study the corporate philanthropy actions via four elements of competitive environment. Corporate philanthropy can improve the corporate competitiveness only in good social and economic benefits (Campbell, Gulas and Gruca, 1999). Altruists, such as Sanchez (2000), proposed that corporate philanthropy asks for no return and is the embodiment of social welfare maximization. Andreoni and Payne (2011) argued that potential altruistic motivations can drive 
corporate philanthropic strategy to help firms gain public praise. Political motivational perspective reflects that firms are affected by the political environment and make a philanthropic decision in order to increase profit and reduce external penalties. Haley (1991) argued that corporate philanthropy was a kind of managerial masques for managers to achieve their own management purposes.

The four motivations above can explain almost all corporate philanthropic actions. Political motivational perspective is the most significant in China when considering China's unique cultural environment and political system. From the cultural perspective, China's philanthropic culture has the characteristics of introversion compared to the open philanthropic culture in Western society. Along with five thousand years of civilized history, China's society has been deeply influenced by Confucianism that benevolence is the core idea (Wang and Qian, 2011). One famous Mencius' saying is: 'Gentlemen cherish all things but not love; love ordinary people but not dear; so gentlemen dear relatives then love ordinary people and cherish everything at last' (Lau, 2003, p. 53). That means philanthropy emphasizes to the relatives and close friends but not strangers and firms in China rarely make philanthropic decisions under altruistic motivational perspective. Meanwhile, China's philanthropic culture also has a political characteristic. China's long imperial rule produced the political priority culture. 'The universe belongs to all and the state power works hard for all' from Sun Yat-sen's famous saying is the direct manifestation of dominant thought (Chen and Payne 1946, p. vi). Over emphasis on the philanthropy of the rulers led to the lack of private philanthropic actions.

From the political system perspective, as a socialist political system, the Communist Party of China is firmly in power. One-party government controls almost all resources and is difficult to prevent corruption. The power-for-money deal between the government and firms is the way for firms to obtain key resources and achieve fast development especially in some industries such as real estate and mining energy that rely on the government's authorization (Wang and You 2012). In order to achieve the balance between government and public relations, philanthropy is the viable strategy to not only exchange political chips and reduce regulation from the government, but also to appease public opinion then achieve a balance among the three (Zhao, Bai and Zhao, 2014).

\section{Performance Feedback and Philanthropic Choice}

Based on the previous research on performance feedback and behavioural theory, firms will adjust the strategies according to aspiration level (Cyert and March, 1963). Decision-makers will search for solutions when corporate performance is lower than aspiration level. As an optional strategy with resource cost and possibility of changing corporate image, strategic corporate philanthropy is inherently risky (Godfrey 2005). However, this may be a good solution that increases revenue because of better corporate image and higher degree of media attention. Wang and Qian (2011) also proved that strategic philanthropy is risky, but it's usually the solution that decision-makers choose to change the status quo. Therefore, the hypothesis can be inferred as follows:

Hypothesis 1. Firms with poor ROA are positively likelihood of doing philanthropy.

\section{The Impact of Corporate Philanthropy on Corporate Performance}

Previous studies on the relationship between corporate philanthropy and corporate performance showed the results for two different directions. From the benefits of corporate performance, advertising effectiveness, building reputation, attracting resources, establishing competitive advantages are usually the main benefits that can be achieved from corporate philanthropy. File and Prince (1998) proposed that corporate philanthropy can expand the sales of products, that is conducive to improving the brand awareness of the product. Navarro (1988) found that 
corporate philanthropy can be tax deductible and has the effect of advertising to achieve development goals. In the perspective of strategic philanthropy, Porter and Kramer (2002) claimed that corporate philanthropy can acquire the benefits of business and society. As one strategic investment, philanthropy can help firms get intangible assets such as improving the competitive environment, establishing good cooperative relations with suppliers or customers. Positive stakeholder responses and political access from the socio political legitimacy are also the benefits of corporate performance by making philanthropic decisions (Wang and Qian, 2011).

On the other hand, as corporate philanthropy is not the direct function to influence corporate performance, several risk points exist between the two and may cause loss of performance. Cash flow and other effective resources are used by philanthropy cause the decline in corporate value (Windsor, 2001). Werbel and Carter (2002) pointed that the CEO's personal qualities impact on the corporate financial performance such that corporate philanthropy may become one means to achieve personal interests instead of corporate own interests and this loss has been defined as the agency cost.

Till now, it can be seen from the previous studies that most scholars approved that corporate philanthropy has a positive impact on corporate performance based on Corporate Social Responsibility and a small group of scholars argued that the impact is negative. However, the negative impact just exists in some special external environment that does not meet the situation in China. Although there is definite evidence that the impacts of corporate philanthropy on corporate performance are both positive and negative, the relevant literature that studied the relationship between corporate philanthropy and corporate performance in China has showed that positive impact was greater than negative impact (Gao, Faff and Navissi, 2012, Wang and Qian, 2011). Then, these lead to hypothesize the following:

Hypothesis 2. Corporate philanthropy has a positive impact on corporate performance.

\section{The Moderating Effect of the Political Environment of Industry}

The literature review above has explained that some industries in China have a deep relationship with the government in the one-party political system. The firms in these industries aim to take resources from the government and reduce the risk of regulation so philanthropy has become the way of exchange. Hittman, (2005) pointed that firms with good relationships with their government can reduce the risk of policy change and increase their financial performance. As corporate philanthropy meets the need of government which want to provide social service, so firms will get more benefits from corporate philanthropy when they have more functions to connect with the government (Hittman and Hitt, 1999). Wang and Qian (2011) also supported that the firms obtain political benefit from the corporate performance in the right political environment. So the following hypothesis can be assumed:

Hypothesis 3. The positive impact of corporate philanthropy on corporate performance is stronger in a higher-level political environment of industry.

\section{Methodology}

\section{Sample and Data Collection}

The sample was selected from all China's firms listed on the Shanghai Stock Exchange or the Shenzhen Stock Exchange between 2008 and 2009 and the number of sample size is 1,243. The reason for choosing 2008 and 2009 as the sample year is that the study based on these two years has the characteristics of validity and representation. Due to the occurrence of the strong earthquake in Sichuan Province in May 2008, corporate philanthropy became a focus of public attention while strengthening its impacts (Gao, Faff and Navissi, 2012). In this study, data for Asia Pacific Institute of Advanced Research (APIAR)

DOI : 10.25275/apjabssv4i1bus5 
firms were collected from the China Stock Market and Accounting Research (CSMAR) Database which is the mainstream research database established by a China's private service agency and corporate annual reports. The data of corporate philanthropy were collected from the State Commerce Ministry, the China Charity Federation, the China's Red Cross and corporate website pages.

\section{Dependent Variables}

Philanthropic choice was a dummy variable that records whether the sample corporations chose and performed strategic philanthropy events in the whole year (Wang and Qian, 2011). It was coded as 1 if there was an accurate record of one corporation's philanthropy events. It was coded as 0 otherwise.

Return on assets (ROA) was employed to measure corporate performance as the dependent variable. ROA, calculated as net profit over total assets, is the most widely used accounting measure of corporate performance. ROA shows corporate profitability, liquidity and level of governance, so the contribution of corporate philanthropy is directly reflected by ROA (Ashbaugh-Skaife et al. 2008).

\section{Independent Variables}

Philanthropy was used as the independent variable to show the investment of corporate philanthropy in the whole year (Wang and Qian, 2011).

Return on assets (ROA) was also used as the dependent variable in a different equation. ROA was the dummy variable here and was coded as 1 if one corporate ROA was lower than the average ROA and was coded as 0 if one corporate ROA was higher than the average ROA. Compared with the dependent variable, ROA was calculated in different years.

\section{Moderating Variables}

Industry was used as the moderating variable. In order to reflect the difference of political environment among different industries, this variable should be coded. The industry of one firm was coded as 1 if it involves real estate, tobacco, beverages, mining energy industries which have a high level of political environment and was coded as o if it was involved in other industries. Industry can moderate the relationship between corporate philanthropy and performance.

\section{Control Variables}

Firm size, firm age, number of shareholders, debt ratio and regional marketization index (NERI) were used as the control variables. Firm size, calculated as the log of the number of employees, impacts a firm's ability to acquire resource. Larger firms will benefit more from the market economy and have a better public opinion and concern (Roberts and Dowling, 2002). Firm age is calculated as the time span from firms' establishment. Longer firm age means more mature corporate structure and social connections. Number of shareholders, collected from the corporate annual reports, is connected with the corporate decisions of social responsibilities. Debt ratio, calculated as total liabilities over total assets, reflects the healthy development and operational capacity of firms (Barnett and Salomon 2006). One firm with appropriate debt ratio has more confidence to make a philanthropic decision with enough resource. NERI, collected from Annual Report of China's Regional Marketization Index reported by the government program (Fan, Wang and Zhu, 2010), shows the level and development of marketization of one firm's headquarters area. High index of regional marketization will enlarge the effect of corporate decisions and activities and reduce the degree of dependence on the government. 


\section{Equation}

The analysis in this study consists of two stages. Each equation used to test hypotheses shows below: Table 1: First-stage variables

\begin{tabular}{|c|c|c|c|c|c|c|c|c|c|c|}
\hline & Variables & Mean & s.d. & 1 & 2 & 3 & 4 & 5 & 6 & 7 \\
\hline 1. & Philanthropic choice & 0.83 & 0.38 & & & & & & & \\
\hline 2. & $\mathrm{ROA}$ & 0.38 & 0.49 & -0.11 & & & & & & \\
\hline 3. & Industry & 0.13 & 0.33 & 0.06 & -0.11 & & & & & \\
\hline 4. & Firm size & $7 \cdot 52$ & 1.48 & 0.08 & 0.03 & 0.00 & & & & \\
\hline 5. & Firm age & 2.35 & 0.51 & -0.09 & 0.09 & 0.01 & -0.07 & & & \\
\hline 6. & Number of shareholders & 10.52 & 1.04 & 0.04 & 0.11 & 0.12 & 0.39 & 0.22 & & \\
\hline 7. & Debt ratio & 0.54 & 0.26 & -0.08 & 0.22 & 0.03 & 0.04 & 0.13 & 0.06 & \\
\hline 8. & NERI & 2.16 & 0.25 & 0.07 & -0.08 & -0.04 & -0.06 & -0.05 & 0.02 & -0.05 \\
\hline
\end{tabular}

The dependent variable is measured for year $\mathrm{t}$; other variables, for year $\mathrm{t}-1 ; \mathrm{n}=1,243$.

Table 2:Second-stage variables

\begin{tabular}{|c|c|c|c|c|c|c|c|c|c|c|}
\hline & Variables & Mean & s.d. & 1 & 2 & 3 & 4 & 5 & 6 & 7 \\
\hline 1. & ROA & 0.06 & 0.07 & & & & & & & \\
\hline 2. & Philanthropy & 10.98 & $5 \cdot 32$ & 0.19 & & & & & & \\
\hline 3. & Industry & 0.13 & 0.33 & 0.22 & 0.11 & & & & & \\
\hline 4. & Firm size & $7 \cdot 52$ & 1.48 & 0.01 & 0.19 & 0.00 & & & & \\
\hline 5. & Firm age & 2.35 & 0.51 & -0.05 & -0.09 & 0.01 & -0.07 & & & \\
\hline 6. & Number of shareholders & 10.52 & 1.04 & 0.00 & 0.12 & 0.12 & 0.39 & 0.22 & & \\
\hline 7 . & Debt ratio & 0.54 & 0.26 & -0.30 & -0.06 & 0.03 & 0.04 & 0.13 & 0.06 & \\
\hline 8. & NERI & 2.16 & 0.25 & 0.06 & 0.08 & -0.04 & -0.06 & -0.05 & 0.02 & -0.05 \\
\hline
\end{tabular}

The dependent variable is measured for year $t$; other variables, for year $t-1 ; n=1,243$.

$$
\begin{aligned}
P_{t}= & \alpha_{0}+\alpha_{1} \text { ROA }_{t-1}+\alpha_{2} \text { industry }_{t-1}+\alpha_{3} \text { firmsize }_{t-1}+\alpha_{4} \text { firmage }_{t-1} \\
& +\alpha_{5} \text { numberofshareholder }_{t-1}+\alpha_{6} \text { debtratio }_{t-1}+\alpha_{7} \text { NERI }_{t-1}+\varepsilon_{t-1} \\
Y_{t}= & \beta_{0}+\beta_{1} \text { philanthropy }_{t-1}+\beta_{2} \text { moderator }_{t-1}+\beta_{3} \text { philanthropy }_{t-1} \times \text { moderator }_{t-1} \\
& +\beta_{4} \text { firmsize }_{t-1}+\beta_{5} \text { firmage }_{t-1}+\beta_{6} \text { numberofshareholders }_{t-1} \\
& +\beta_{7} \text { debtratio }_{t-1}+\beta_{8} \text { NERI }_{t-1}+\varepsilon_{t-1}
\end{aligned}
$$

In the first binary logistic regression equation, $\mathrm{P}_{\mathrm{t}}$ is the Philanthropic choice. $\varepsilon$ is the stochastic disturbance. ROA and Industry are dummy variables. In the second linear regression equation, $\mathrm{Y}_{\mathrm{t}}$ is the corporate performance in the next year. Moderator is the industry code that represents the political environment of industry in the hypotheses. $\varepsilon$ is the stochastic disturbance.

\section{Results}

\section{Descriptive Statistics and Correlation Matrix}

Table 1 and Table 2 show the descriptive statistics and correlation matrix of two analyses. In the first-stage analysis, Philanthropy choice (mean o.83) and Industry (mean 0.13) are the dummy variables and the mean value reflects the ratio of 1 and o. ROA, Industry, Firm size, Number of shareholders and NERI are found to have a positive correlation with Philanthropy choice but the values are small (the largest one is 0.09). Firm age and Debt ratio have a negative correlation. The correlation level of each variable is low and the significant correlation is found between Firm size and Number of shareholders (0.39). This can be explained by taking into account the 
Table 3:Results of binary logistic regression

\begin{tabular}{llll}
\hline Variables & Model 1 & Model 2 & Model 3 \\
\hline Intercept & -0.23 & -0.76 & -0.23 \\
Firm size & $0.13^{*}$ & $0.13^{*}$ & $0.14^{*}$ \\
Firm age & $-0.53^{* *}$ & $-0.52^{* * *}$ & $-0.51^{* *}$ \\
Number of shareholders & 0.08 & 0.10 & 0.08 \\
Debt ratio & $-0.55^{*}$ & -0.39 & -0.41 \\
NERI & $0.75^{*}$ & $0.70^{*}$ & $0.72^{*}$ \\
ROA & & $0.49^{* * *}(\operatorname{Exp~1.63)}$ & $0.45^{* * *}(\operatorname{Exp~1.57)}$ \\
Industry & & & $-0.48^{+}(\operatorname{Exp} 0.62)$ \\
Log-likelihood & -555.31 & -550.52 & -548.76 \\
$\Delta \chi^{2}$ & & $2.75^{* *}$ & 2.12 \\
\hline
\end{tabular}

The dependent variable is measured for year $t$; other variables, for year $t-1 ; n=1,243$.

${ }^{+} \mathrm{p} \leq .10 ;{ }^{*} \mathrm{p} \leq .05 ;{ }^{* *} \mathrm{p} \leq .01 ;{ }^{* * *} \mathrm{p} \leq .001$

Table 4:Results of linear regression

\begin{tabular}{lllll}
\hline Variables & Model 1 & Model 2 & Model 3 & Model 4 \\
\hline Intercept & $0.08^{* *}$ & $0.07^{* * *}$ & $0.07^{* *}$ & $0.09^{* * *}$ \\
Firm size & 0.01 & -0.01 & 0.01 & 0.00 \\
Firm age & -0.01 & 0.01 & 0.01 & 0.01 \\
Number of shareholders & 0.00 & -0.01 & -0.01 & -0.01 \\
Debt ratio & $-0.09^{* * *}$ & $-0.08^{* * *}$ & $-0.09^{* * *}$ & $-0.09^{* * *}$ \\
NERI & 0.01 & 0.01 & 0.01 & 0.01 \\
Philanthropy & & $0.01^{* * *}$ & $0.01^{* * * *}$ & $0.01^{* * * *}$ \\
Industry & & & $0.05^{* * * *}$ & $-0.03^{+}$ \\
Philanthropy×Industry & & & $0.01^{* * *}$ \\
F & $25.96^{* * *}$ & $28.51^{* * *}$ & $35.53^{* * *}$ & $35.08^{* * *}$ \\
$\mathrm{R}^{2}$ & 0.10 & 0.12 & 0.17 & 0.19 \\
Adjust $\mathrm{R}^{2}$ & 0.09 & 0.12 & 0.16 & 0.18 \\
\hline
\end{tabular}

The dependent variable is measured for year $t$; other variables, for year $t-1 ; n=1,243$.

${ }^{+} \mathrm{p} \leq .10 ;{ }^{*} \mathrm{p} \leq .05 ;{ }^{* *} \mathrm{p} \leq .01 ;{ }^{* * *} \mathrm{p} \leq .001$

actual situation. In the second-stage analysis, the maximum mean of variables is Philanthropy (10.98) that has the largest standard deviation (5.32). Philanthropy, Industry, Firm size, Number of shareholders and NERI are found to have a positive correlation with ROA and Firm age and Debt ratio have a negative correlation. Overall, multicollinearity is not an important problem in the analysis and this is a good foundation for regression analysis.

\section{First-stage Logistic Regression Analysis}

Table 3 shows the results of logistic regression of Philanthropy choice on different variables. The analysis contains three steps of models. Model 1, the first basic model, presents the coefficient value of control variables and intercept. Firm size, Firm age, Debt ratio and NERI were significant. Among them, Firm size and NERI were more likely to contribute to the dependent variable. In Model 2, ROA was added to the regression and showed a significant result and was more likely to engage in the dependent variable $(\mathrm{p}<.001)$. Industry was added to the regression in Model 3. However, its significance is not so obvious $(\mathrm{p}=.08)$.

From the overall perspective, it can be known from analyzing the data of Philanthropic choice that 214 of 1,243 firms didn't choose philanthropy, accounting for $82.8 \%$. Log-likelihood value of each model was large enough to ensure the overall reliability. $\Delta \chi^{2}$ means the change value of Asia Pacific Institute of Advanced Research (APIAR)

DOI : 10.25275/apjabssv4i1bus5 
Chi square from each model. $\Delta \chi^{2}$ from Model 1 to Model 2 was positive and significant and the next $\Delta \chi^{2}$ was not significant. Combined with the coefficient of new variables, it is clear that firms with poor ROA are positively likelihood of doing philanthropy and Industry has no impact.

\section{Second-stage Linear Regression Analysis}

Table 4 shows the results of the linear regression of ROA on different variables. Five different Control variables were brought into the regression equation in Model 1 and then the independent variable Philanthropy in Model 2. Model 3 added the moderating dummy variable Industry and the interaction term of independent variable and moderating variable was finally added. The effect of newly added variables can be reflected via this hierarchical multivariate linear regression process.

In Model 1 and Model 2, Debt ratio and Intercept showed the significant relationship with corporate performance. In all the control variables, Firm age and NERI were positive associated with ROA and other variables were negatively associated with ROA. As for the independent variable, Philanthropy was positively associated with ROA and the relationship was significant ( $\mathrm{p}<$.001). Though the coefficient value was small, the positive impact of corporate philanthropy on corporate performance can be proved. Simultaneously, The value of adjust R2 in Model 2 was larger than that in Model 1 and this means that the independent variables had explanatory power to ROA.

Model 3 and Model 4 analyzed the impact of the moderating variable on the relationship between corporate philanthropy and corporate performance. In Model 3, the coefficient value of Industry was 0.05 and $\mathrm{p}<0.001$. The interaction term in Model 4 was positively associated with the dependent variable and the result was significant $(\mathrm{p}<.001)$. Therefore, it can be seen from Model 3 and Model 4 that the moderating variable Industry had a positive effect on the impact of corporate philanthropy on corporate performance.

Overall, $\mathrm{F}$ values of the four models were all over 25 and those were large enough to explain the analysis. Each $\mathrm{F}$ value was significant $(\mathrm{p}<$.001), so the whole regression analysis is meaningful and its result is credible. The values of Adjust $\mathrm{R} 2$ are $0.09,0.12,0.16,0.18$ respectively and each value is larger than the value of the previous model, which ensures that the variables added to each regression progress are meaningful and enhance the explanatory power of the model.

\section{Discussion}

In this study, it has been argued that performance feedback affects corporate philanthropic choice. Through the case study above, it is determined that past poor performance of firms is likelihood to make a strategic choice of corporate philanthropy. As an optional strategy with resource cost and possibility of changing corporate image, strategic corporate philanthropy is inherently risky (Godfrey, 2005). The essence of the work of an organization's decision-makers is to avoid risks and ensure profits so active corporate philanthropy is often not the firms' first strategic choice. However, for those firms who are facing poor performance, top management teams will increase the risk tolerance, hoping to find a way to improve the financial performance through some high-level risky strategic choices (Greve, 2003). In this case, corporate philanthropy is often the strategic choice with a great hope of improving the image and reputation. The results of this study suggest that firms with past poor performance are more likely to endorse corporate philanthropy.

From the results of the binary logistic regression, it has been proved that philanthropic choice has no relationship with industry. As the effect of corporate philanthropy in different industries is quite different, it is easy to speculate that firms in some industries are willing to make a philanthropic choice to get greater return. Two points can explain why there is no tendency. First, the profits of philanthropy and possible risk are not equivalent. The risk from corporate 
philanthropy is a kind of external risk and can affect customers and investors which are the basis of one firm so decision-makers will choose strategic philanthropy when they face a certain degree of difficulties. Secondly, in a high level of political environment industry in China, the main motivation of firms is to get useful resources and not the public image and they often choose to make philanthropy in a project related to the government or some political persons. Simultaneously, such active philanthropy is easily misinterpreted as a kind of atonement for corruption and will make a counter-effect from the public (Wang and Qian, 2011).

In this study, the relationship of corporate philanthropy and corporate performance in China can be determined. Although some scholars have argued the negative relationship between the two, positive relationship can be proved from the linear regression by using the case of Chinese listed firms. Based on the Corporate Social Responsibility, corporate philanthropy reflects that firms fulfil their social responsibility. They can obtain the return from it in ways of good reputation, recognition and social image. In the Chinese business environment, strategic philanthropy is valuable. As China has the largest number of population and effective media channels, firms can widen their circulation through the event of corporate philanthropy in a short time and this may ensure in a highest degree possible that firms obtain the benefits from social responsibility.

In this part of study, the most important issue is to determine the moderating effect of industry. China is the country with a high political environment. Because of socialism and Communist Party in power in the long term, corruption is the systematic problem which cannot be solved. The government controls the key resources and it becomes the capital that government officer use to corrupt. In this case, some industries in high level political environment will be affected by the government. Firms in these industries such as real estate, tobacco, beverages, mining energy need to obtain the survival resources from the government, so corporate philanthropy becomes the method for firms to exchange the resources and the government can also get the benefits from the philanthropy event. Based on the Resource Dependent Perspective, firms in the industries with high level political environment can get more benefits from corporate philanthropy than the firms in the industries with low level political environment. This effect is the moderating effect which moderates the relationship between philanthropy and ROA. Figure 1 shows the moderating effect of industries directly. Industries at different levels of the political environment cause the different tendency between corporate philanthropy and ROA. Obviously, the tendency of the industry in high level political environment is more remarkable.

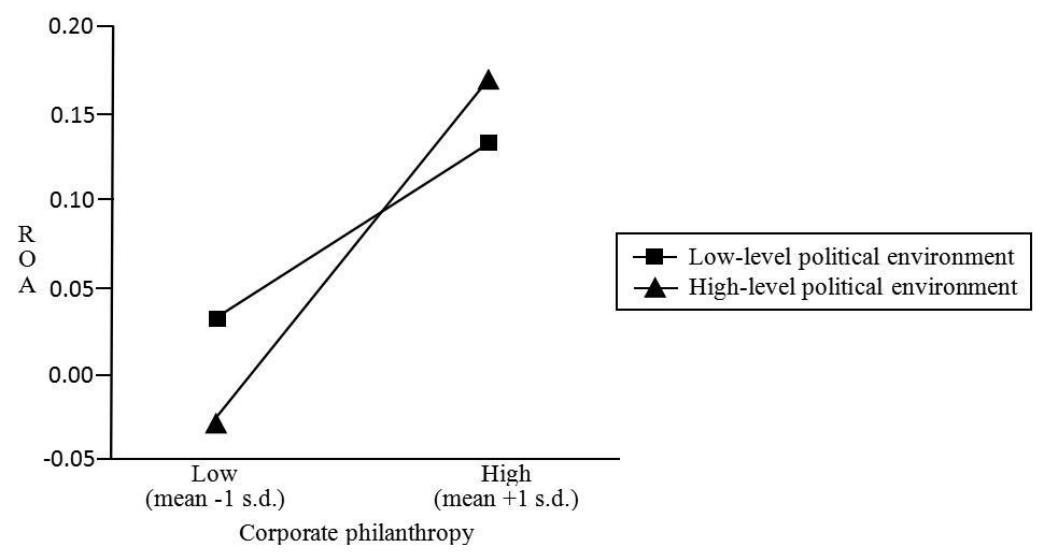

Figure 1: Moderating effect of industry between corporate philanthropy and ROA

There are still some limitations in this study. Firstly, only one form of Corporate Social Responsibility was discussed in this study. Corporate philanthropy is the direct manifestation of Asia Pacific Institute of Advanced Research (APIAR)

DOI : 10.25275/apjabssv4i1bus5 
the corporate fulfilment of social responsibility and can be quantified in order to use for research. There are no other main variables existed in current research. Further studies need to focus on finding variables that can represent CSR such as environment and community events. When more variables can be added to the study, the effect of CSR on corporate performance will be studied more accurately.

Secondly, there were some limitations in the process of collecting corporate philanthropic data in this study. Some corporate philanthropic data are either actively disclosed in the annual reports or promoted by media in order to achieve strategic propaganda. However, there are some philanthropic choices that were decided by personal behavior of top management and the data is hard to collect from the public sources. This may cause the problem of inaccurate results of analysis. In order to solve problem, further studies need to find a method that can involve more philanthropic data such as the improved specific data mining method.

Moreover, this study uses cross-sectional data because of the complexity of data collection. Cross-sectional data can directly be used to analyze a short period of relationship between corporate philanthropy and corporate performance. However, it may cause the bias of results as external factors are special and the results are easily affected by the external environment. If possible, further studies should use panel data which covers a long period of philanthropic data and corporate financial data to analyze the overall impact between corporate philanthropy and corporate performance.

Lastly, due to the late development of China's stock market system compared with other developed and developing countries, only a small part of firms with enough firm size and good performance can be listed in the first decade of the 21st century. The results can be reflected in the listed firms, but not all firms. This is an institutional defect that cannot be avoided in China's business studies. As time progressed, the results will be more accurate in similar research and further research could prove the results from this study with stronger panel data after ten or twenty years.

\section{Conclusion}

This study aims to determine the motivation of corporate philanthropic behavior and identify the relationship between corporate philanthropy and corporate performance with the moderating effect of different level political environment of industries. By analyzing the data of China's listed firms in 2008 and the data of corporate philanthropic events, it can be found that past poor performance increases the possibility of philanthropic choice. Corporate philanthropy has a positive effect on corporate performance and the firms in high level political environment of industries can get more benefits from the strategic philanthropy. Based on these results, further studies can analyze the relationship between corporate philanthropy and corporate performance in a new perspective and better data to develop this topic. 


\section{References}

i. Andreoni, J. \& Payne, A., 2011. Is crowding out due entirely to fundraising? Evidence from a panel of charities. Journal of Public Economics, 95(5), pp. 334-343.

ii. Ashbaugh-Skaife, H., Collins, D., Kinney, W. \& Lafond, R., 2008. The Effect of SOX Internal Control Deficiencies and Their Remediation on Accrual Quality. The Accounting Review, 83(1), pp. 217-250.

iii. Aupperle, K., Carroll, A. \& Hatfield, J., 1985. Empirical Examination of the Relationship between Corporate Social Responsibility and Profitability. Academy of Management Journal, 28(2), pp. 446463 .

iv. Barnett, M. \& Salomon, R., 2006. Beyond Dichotomy: The Curvilinear Relationship between Social Responsibility and Financial Performance. Strategic Management Journal, 27(11), pp. 1101-1122.

v. Campbell, D., Moore, G. \& Metzger, M., 2002. Corporate Philanthropy in the U.K. 1985-2000: Some Empirical Findings,. Journal of Business Ethics, 39(3), pp. 29-41.

vi. Campbell, L., Gulas, C. \& Gruca, T., 1999. Corporate Giving Behaviour and Decision-maker Social Consciousness. Journal of Business Ethics, 19(4), pp. 375-383.

vii. Chen, S. \& Payne, R., 1946. Sun Yat-Sen: A Portrait. [Art] (John Day, New York. ).

viii. Fan, G., Wang, X. \& Zhu, H., 2010. China's Marketization Index-the Report of Relative Process of Regional Markets in 2009, Beijing: Economic Science Press.

ix. Frooman, J., 1997. Socially Irresponsible and Illegal Behavior and Shareholder Wealth, A MetaAnalysis of Event Studies. Business \& Society, 36(3), pp. 221-249.

x. Gao, F., Faff, R. \& Navissi, F., 2012. Corporate philanthropy: Insights from the 2008 Wenchuan Earthquake in China. Pacific-Basin Finance Journal, 20(3), pp. 363-377.

xi. Godfrey, P., 2005. The Relationship Between Corporate Philanthropy And Shareholder Wealth: A Risk Management Perspective. Academy of Management Review, 30(4), pp. 777-798.

xii. Greve, H., 2003. A Behavioral theory of R\&D expenditures and innovations: Evidence from shipbuilding. Academy of Management Journal, 46(6), pp. 685-702.

xiii. Griffin, J. \& Mahon, J., 1997. The Corporate Social Performance and Corporate Financial Performance Debate: Twenty-Five Years of Incomparable Research. Business \& Society, 36(1), pp. 531.

xiv. Haley, U., 1991. Corporate Contributions As Managerial Masques: Reframing Corporate Contributions As Strategies to Influence Society. Journal of Management Studies, 28(5), pp. 485510 .

xv. Hittman, A., 2005. Politicians on the board of directors: Do connections affect the bottom line? Journal of Management, 31(3), pp. 464-481.

xvi. Hittman, A. \& Hitt, M., 1999. Corporate political strategy formulation: A model of approach, participation, and strategy decisions. Academy of Management Review, 24(4), pp. 825-842.

xvii. Lau, D., 2003. Mencius. Hong Kong: The Chinese University Press.

xviii. Navarro, P., 1988. Why do corporations give to charity?. Journal of business, 61(1), pp. 65-93.

Asia Pacific Institute of Advanced Research (APIAR)

DOI : 10.25275/apjabssv4i1bus5 
xix. Patten, D., 2008. Does the market value corporate philanthropy? Evidence from the response to the 2004 Tsunami relief effort. Journal of Business Ethics, 81(3), pp. 599-607.

xx. Porter, M. \& Kramer, M., 2002. The competitive advantage of corporate philanthropy. Harvard business review, 80(12), pp. 56-68.

xxi. Roberts, P. \& Dowling, G., 2002. Corporate Reputation and Sustained Superior Financial Performance. Strategic Management Journal, 23(12), pp. 1077-1093.

xxii. Sanchez, C., 2000. Motives for Corporate Philanthropy in El Salvador: Altruism and Political Legitimacy. Journal of Business Ethics, 27(4), pp. 363-376.

xxiii. Wang, H., Choi, J. \& Li, J., 2008. Too Little or Too Much? Untangling the Relationship between Corporate Philanthropy and Firm Financial Performance. Organization Science, 19(1), pp. 143-159.

xxiv. Wang, H. \& Qian, C., 2011. Corporate Philanthropy and Corporate Financial Performance: The Roles of Stakeholder Response and Political Access. Academy of Management Journal, 54(6), pp. 11591181.

xxv. Wang, J. \& Coffey, B., 1992. Board composition and corporate philanthropy. Journal of Business Ethics, 11(10), pp. 771-778.

xxvi. Wang, Q., Dou, J. \& Jia, S., 2016. A Meta-Analytic Review of Corporate Social Responsibility and Corporate Financial Performance. Business \& Society, 55(8), pp. 323-345.

xxvii. Wang, Y. \& You, J., 2012. Corruption and firm growth: Evidence from China. China Economic Review, 23(2), pp. 415-433.

xxviii. Werbel, J. \& Carter, S., 2002. The CEO's Influence on Corporate Foundation Giving. Journal of Business Ethics, 40(1), pp. 47-6o.

xxix. Windsor, D., 2001. The Future of Corporate Social Responsibility. International Journal of Organizational Analysis, 9o(3), pp. 225-256.

xxx. Zhao, S., Bai, X. \& Zhao, Y., 2014. Handbook of Research on Entrepreneurs Engagement in Philanthropy: Perspectives. Northampton: Edward Elgar. 